\title{
The association between occupational loading and spine degeneration on imaging - a systematic review and meta- analysis
}

\author{
Luciana G. Macedo ${ }^{1 *}$ (D) and Michele C. Battié2
}

\begin{abstract}
Background: There are inconsistencies in findings regarding the relationship of occupational loading with spinal degeneration or structural damage. Thus, a systematic review was conducted to determine the current state of knowledge on the association of occupational loading and spine degeneration on imaging.

Methods: We performed electronic searches on MEDLINE, CINAHL and EMBASE. We included cross-sectional, case control and cohort studies evaluating occupational loading as the exposure and lumbar spine structural findings on imaging as the outcomes. When possible, results were pooled.

Results: Seventeen studies were included in the review. Ten studies evaluated the association of occupational loading with disc degeneration (signal intensity), four of which were pooled into a meta-analysis. Of the 10 studies, only two did not identify a relationship between occupation loading and disc degeneration. A meta-analysis including four of the studies demonstrated an association between higher loading and degeneration for all spinal levels, with odds ratios between 1.6 and 3.3. Seven studies evaluated disc height narrowing and seven evaluate disc bulge, with six and five identifying an association of loading and with imaging findings respectively. Three studies evaluated modic changes and one identified and association with occupational load.

Conclusions: There was moderate evidence suggesting a modest association between occupational loading and disc degeneration (signal intensity), and low-quality evidence of an association between occupational loading and disc narrowing and bulging.
\end{abstract}

Keywords: Occupational load, Spine degeneration, Disc degeneration, Disc height, Imaging, Magnetic resonance imaging, X-ray

\section{Background}

The cumulative or repetitive injury model was once a dominant paradigm of spine degeneration [1]. Thus, heavy occupational physical loading activities have long been suspected of increasing spine degeneration. However, inconsistencies between study findings, with some supporting this association [2,3] and other not $[4,5]$, have led to controversy and uncertainty about the

\footnotetext{
* Correspondence: macedol@mcmaster.ca

${ }^{1}$ School of Rehabilitation Science (Physiotherapy), Faculty of Health Sciences, McMaster University, 1400 Main St. W. Room 441, IAHS, Hamilton, ON L8S 1C7, Canada

Full list of author information is available at the end of the article
}

relationship between physical loading and lumbar spine degeneration. Furthermore, recent studies suggest that the structures of the spinal column, including the intervertebral discs, adapt and may even benefit from greater routine physical loading [1].

Controversy still exists between the relationship of occupational load and low back pain [6]. However, given the subjective nature of pain evaluation and the high prevalence of back pain in general, studies depicting the association between pain and occupation load always have large room for bias. The use of objective measures of spine degeneration to evaluate the impact of occupational load on the spine can provide a solution to better

(c) The Author(s). 2019 Open Access This article is distributed under the terms of the Creative Commons Attribution 4.0 International License (http://creativecommons.org/licenses/by/4.0/), which permits unrestricted use, distribution, and reproduction in any medium, provided you give appropriate credit to the original author(s) and the source, provide a link to the Creative Commons license, and indicate if changes were made. The Creative Commons Public Domain Dedication waiver (http://creativecommons.org/publicdomain/zero/1.0/) applies to the data made available in this article, unless otherwise stated. 
understanding this relationship. The evaluation of spine degeneration on imaging is both a reliable and objective measure to evaluate the effects of repetitive load on the spine, which in turn may mediate the occurrence of back pain in this population. Although spine degeneration on imaging is not synonym of back pain, spine degeneration on imaging have been found to be associated with an increased risk for low back pain [7] and increased risk of recurrent episodes [8].

Given the inconsistencies in the literature about the association of occupational load and spine degeneration, the objective of this study was to systematically review the literature on the association of occupational loading and spine degeneration observed on imaging. Occupational loading was described as loading conditions occurring during occupational activities, such as lifting and manual handling or comparisons between specific occupations.

\section{Methods}

A protocol for the study was developed a priori following the PRISMA guidelines and Cochrane Handbook.

\section{Data sources and searches}

A computerised electronic search was performed to identify relevant articles. The search was conducted on MEDLINE (1946 to May 2019), CINAHL (1982 to May 2019) and EMBASE (1988 to May 2019). Key words included in our search were related to 3 domains: imaging (i.e. $x$-ray, radiograph), imaging findings (i.e. disc degeneration, disc height) and load (i.e. manual handling, occupational load). Subject subheadings and word truncations specific for each database were used. There was no language restriction. See Additional file 1 for search strategy section.

Two reviewers screened search results (titles and abstracts) for potentially eligible studies. A third independent reviewer resolved any disagreement for inclusion of trials. Authors were contacted if more information about the trial was needed to allow inclusion of the study.

We also performed a search on the reference lists of the included studies and a search on ISI Web of Sicence (May 2019) for papers that cited the included studies.

\section{Study selection}

Cross-sectional, case-control and cohort studies evaluating occupational loading as the exposure were eligible for inclusion. All studies that evaluated professional athletes and whole body vibration as a form of exposure were included on a separate review. In addition, the study had to evaluate the relationship of loading with lumbar spine structural findings evaluated on diagnostic imaging. Studies that used back pain as an outcome measure were not included. Studies that included patients with pre-existing conditions, such as disc herniation, were excluded from the review as they are more likely to have positive findings on imaging and may provide biased estimates for the relationship under investigation. Two reviewers screened the full text of potentially eligible studies and decided on inclusion. A third independent reviewer resolved any disagreement for inclusion of studies. The reviewers followed a research protocol developed prior to the beginning of the review, which included a checklist of inclusion criteria.

\section{Data extraction and quality assessment}

The methodological quality of the trials was assessed using the Newcastle Ottawa Quality Assessment scale $[9,10]$ for case-control and cohort studies. The maximum value of the scale is 9 (high quality) and the minimum value is 0 (lowest quality). The quality was assessed by independent raters and disagreements were resolved by a third rater. Methodological quality was not an inclusion criterion but was taken into consideration when making conclusions.

Two independent reviewers (LM and research assistants) extracted data from the included studies using a standardized data extraction form. Important characteristics of each study were extracted, such as type of loading, study design, type of imaging, patient population, affiliation of the authors, funding source, and study conclusions. We also extracted the type of outcomes used, and for continuous outcome measurements we extracted mean scores, standard deviations and sample size, and for dichotomous and ordinal outcomes, sample size and number of events per group.

\section{Data synthesis and analysis}

Results were pooled when trials were considered sufficiently homogenous with respect to participant characteristics, exposure and outcomes. $\mathrm{I}^{2}$ was calculated using RevMan 5 to assess statistical heterogeneity. A random effects model was used to pool all available outcomes. $\mathrm{I}^{2}$ was calculated to evaluate statistical heterogeneity of pooled outcomes [11]. When adequate data were presented from the original study, mean differences and standard deviations for continuous outcomes and odds ratios for dichotomous outcomes were calculated. When such information was not available, the information presented in each study was used for interpretation of the results.

The GRADE approach for grading the level of the evidence available was used to summarize the conclusion of this review [11]. Depending on the number and quality of the studies included in the review, the evidence was classified into high, moderate, low or very low quality evidence. 


\section{Results}

\section{Study selection}

The electronic database search resulted in a total of 5363 articles after removing duplicates. Of these, 137 were selected as potentially eligible based on their title and abstract.

After full title screening a total of 16 studies were included in the review. An additional ISI web of science search showed 11 more potentially eligible studies, from which 1 was included in the review. Therefore, the final number of included studies was 17. (Flowchart_Fig. 1).

125 Exclusion for graph only * 27 No outcome of interest $[6,10,12-30,31-35], 11$ no non-exposed group [36-46], 23 not evaluating occupational load [1, 47-53, 54-62], 19 not a cohort study [63-81], 11 included patients on already established conditions, [37, 82-91] 5 no imaging on all groups [92-96], 4 cervical spine [97-100], 1 in vitro, [101] 1 child study [34], 1 cant get full text [102], 3 secondary analysis or study with same population of an already included study, [103-105] 10 studies evaluated whole body vibration alone, [106-115] 9 studies evaluated athletes [116-124].

\section{Study characteristics}

There were 16 original studies evaluating occupational load [2-5, 125-136] including 1 follow-up study [137].
Ten studies evaluated specific job requirements such as occupational lifting or job load summary score [2, 4, 127-130, 132, 133, 135-137] and six compared different types of occupation with different occupational requirements [3, 5, 125, 126, 131, 134]. See Table 1 for study characteristics.

\section{Methodological quality}

The methodological quality demonstrated an overall moderate level of quality, with a minimum of 3 , a maximum score of 8 , and a median and interquartile range of 5 and 3 . The items of the methodological quality scale that were not present in most studies were control of potentially confounding factors and reporting of the response rate of each group.

Three studies included the same population from the Finnish Twin Spine study, but answered different questions related to different outcomes. These studies represent the strongest form of evidence given that controls are identical twins, minimizing possible confounding and familial aggregation [127, 128].

\section{Outcomes}

Ten studies evaluated the impact of loading on disc degeneration, generally assessed through disc signal intensity, representing disc desiccation [2-5, 126-129,

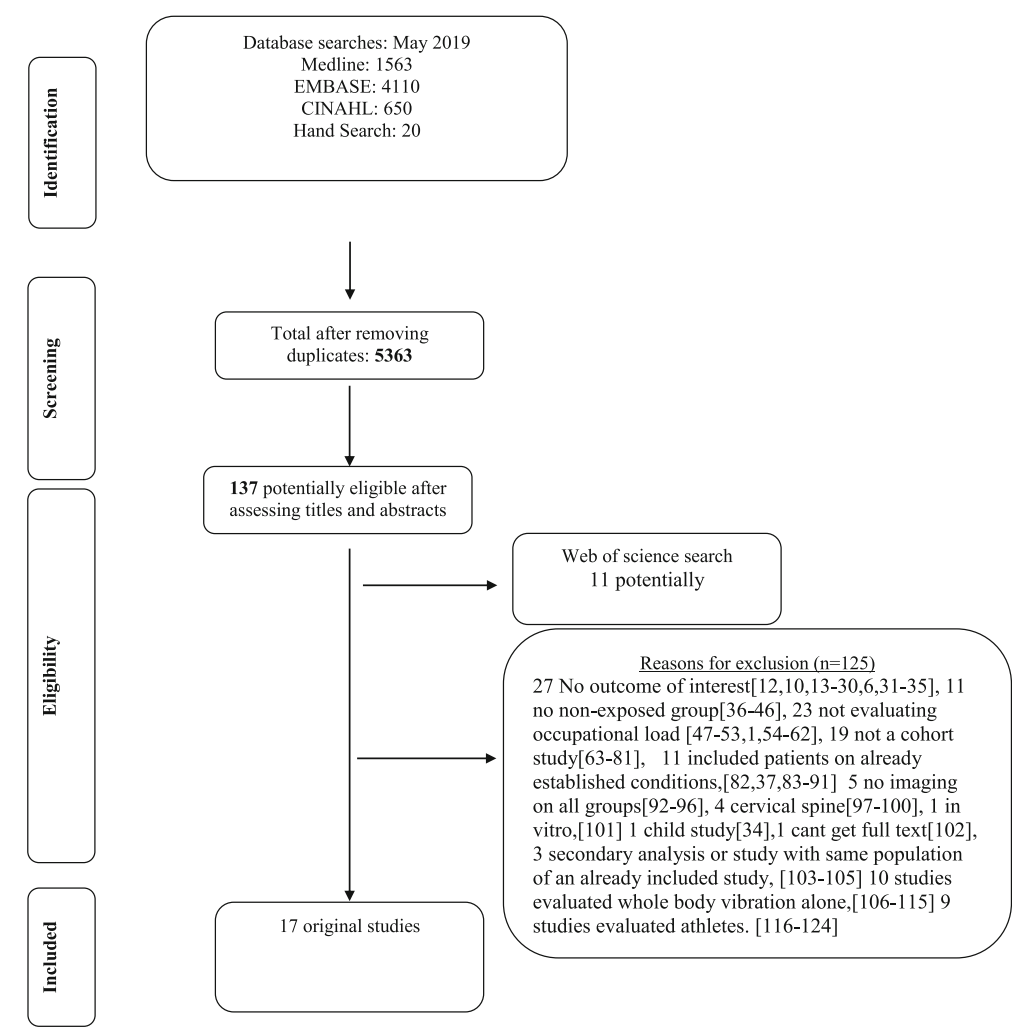

Fig. 1 Flow chart of occupational load systematic review inclusion 
Table 1 Study characteristics

\begin{tabular}{|c|c|c|c|c|}
\hline Author & $\begin{array}{l}\text { Methodological } \\
\text { Quality }\end{array}$ & Imaging & Study Design & Participant information \\
\hline Arevalo et al. 2014 & 5 & MRI & Retrospective cohort study & $\begin{array}{l}N=652 ; 326 \text { patients with established diagnosis of lumbar } \\
\text { disc herniation on MRI and } 326 \text { patients without herniation. } \\
\text { Age range was assessed but not reported. }\end{array}$ \\
\hline Battie et al. 1995 & 6 & MRI & Cross sectional & $\begin{array}{l}\text { Monozygotic twin pairs from the Finnish Twin Cohort selected } \\
\text { based on loading discordances. ( } n=230 \text { twins or } 115 \text { pairs) } \\
\text { Age range from } 35 \text { to } 69 \text { years. }\end{array}$ \\
\hline $\begin{array}{l}\text { Biering-Sorense } \\
\text { et al. } 1985\end{array}$ & 4 & x-ray & Longitudinal cohort study & $\begin{array}{l}666 \text { participants taking part in a population study of } 60 \text {-yerar-old } \\
\text { inhabitants from the area around Glostrip Hospital in the suburbs } \\
\text { of Copenhagen. } \\
\text { All participants were either } 50 \text { or } 60 \text { years of age. }\end{array}$ \\
\hline $\begin{array}{l}\text { Brinckmann et al. } \\
1998\end{array}$ & 5 & -ray & Retrospective cohort study & $\begin{array}{l}355 \text { subjects with long term exposure to heavy physical load } \\
\text { (from different professions) and } 737 \text { healthy controls compiled } \\
\text { from healthy unexposed subjects. } \\
\text { Participants were between } 17 \text { to } 57 \text { years old. }\end{array}$ \\
\hline Elfering et al. 2002 & 3 & MRI & longitudinal cohort study & $\begin{array}{l}46 \text { asymptomatic patients from a group of } 2000 \text { trauma patients } \\
\text { presenting to the university trauma clinic with minor extremity } \\
\text { injuries with complete recovery. } \\
\text { Participants were between } 20 \text { and } 50 \text { years of age. }\end{array}$ \\
\hline $\begin{array}{l}\text { Frymoyer et al. } \\
1984\end{array}$ & 3 & -ray & Cross sectional (retrospective) & $\begin{array}{l}321 \text { random patients from a sample of } 1221 \text { from a previous } \\
\text { study. Only } 285 \text { were included in the occupation vs imaging } \\
\text { study due to reasons such as imaging quality } \\
\text { Participants were between } 18 \text { an d55 years of age. }\end{array}$ \\
\hline Han et al. 2017 & 6 & $\begin{array}{l}\text { MRI and } \\
x \text {-ray }\end{array}$ & Cross sectional & $\begin{array}{l}210 \text { patients with low back pain attending the hospital. All } \\
\text { underwent imaging evaluation and responded to questionnaires } \\
\text { about workload. } \\
\text { Age ranged from } 40 \text { to } 60 \text { years. }\end{array}$ \\
\hline Hangai et al. 2008 & 4 & MRI & cross sectional & $\begin{array}{l}\text { Recruited over } 50 \text { year old to participate in a health promotion } \\
\text { program though newspapers in Japan. Those with imaging were } \\
\text { recruitment. } N=270 \text { ( } 1350 \text { discs) } \\
\text { All participants were between } 51 \text { and } 86 \text { years. }\end{array}$ \\
\hline $\begin{array}{l}\text { Hartwig et al. } \\
1997\end{array}$ & 4 & MRI & Cross sectional & $\begin{array}{l}\text { Recruited } 142 \text { participants from } 35 \text { to } 50 \text { years old that were } \\
\text { either nurse }(n=54) \text {, construction workers }(n=51) \text { or controls } \\
(n=37) \text {. Unclear how controls were selected } \\
\text { All patients were between } 35 \text { and } 50 \text { years old. }\end{array}$ \\
\hline Hung et al. 2014 & 6 & MRI & Cross sectional & $\begin{array}{l}553 \text { workers that carry heavy loads (fruit market workers) versus } \\
\text { walk in clinic patients (most commonly diagnosis was common } \\
\text { cold). After that all participants were assessed using questionnaires } \\
\text { and functional assessment for the amount of lifting load and then } \\
\text { categorized into either low, intermediate, or high lifting loads. } \\
\text { Participants were between } 20 \text { and } 65 \text { years old. }\end{array}$ \\
\hline Luoma et al. 1998 & 8 & MRI & cross sectional & $\begin{array}{l}\text { Patients were extracted from a cohort participating in a study } \\
\text { evaluating occupational effects of LBP. ( } n=164,53 \text { drivers, } 51 \\
\text { carpenters and } 60 \text { office workers). } \\
\text { Participants were between } 40 \text { and } 45 \text { years old. }\end{array}$ \\
\hline $\begin{array}{l}\text { Munoz-Gomez } \\
\text { et al. } 1980\end{array}$ & 5 & -ray & Cross sectional & $\begin{array}{l}\text { Workers from an industry } \\
\text { All participants were between } 19 \text { to } 63 \text { years of age. }\end{array}$ \\
\hline $\begin{array}{l}\text { Riihimaki et al. } \\
1990\end{array}$ & 6 & x-ray & cross sectional & $\begin{array}{l}N=417 \text { Male workers. } 216 \text { concrete reinforcement workers of an } \\
\text { specific area were included and } 201 \text { house painters from a local } \\
\text { union. Painters were matched with concrete workers based on a } \\
5 \text {-year strata. } \\
\text { Participants were between } 25 \text { to } 54 \text { years of age. }\end{array}$ \\
\hline Savage et al. 1997 & 4 & MRI & $\begin{array}{l}\text { cross sectional (only } 60 \% \\
\text { participated in the longitudinal } \\
\text { cohort) }\end{array}$ & $\begin{array}{l}\text { Volunteers from different occupations. } N=149 \text { ( } 24 \text { ambulance } \\
\text { men, } 16 \text { hospital porters, } 40 \text { car production workers, } 12 \text { brewery } \\
\text { drayman and } 57 \text { office workers). } \\
\text { All participants were between } 20 \text { and } 58 \text { years of age and were } \\
\text { divided in two groups } 20-30 \text { and } 31 \text { to } 58 \text { years. }\end{array}$ \\
\hline Schenk et al. 2006 & 7 & MRI & Cross sectional - case control & $\begin{array}{l}N=109 \text { staff of local hospital that worked at least } 20 \mathrm{~h} \text { per week. } \\
(57 \text { nurses and } 52 \text { administration workers) } \\
\text { All participants were between } 45 \text { and } 62 \text { years old. }\end{array}$ \\
\hline
\end{tabular}


Table 1 Study characteristics (Continued)

\begin{tabular}{|c|c|c|c|c|}
\hline Author & $\begin{array}{l}\text { Methodological } \\
\text { Quality }\end{array}$ & Imaging & Study Design & Participant information \\
\hline $\begin{array}{l}\text { Videman et al. } \\
2006\end{array}$ & 7 & MRI & longitudinal cohort study & $\begin{array}{l}\text { Monozygotic twin pairs from the Finnish Twin Cohort selected } \\
\text { based on smoking, exercise or occupational loading discordance. } \\
\text { ( } n=140 \text { twins or } 70 \text { pairs). } \\
\text { All participants were between } 35 \text { to } 69 \text { years of age. }\end{array}$ \\
\hline $\begin{array}{l}\text { Videman et al. } \\
2007\end{array}$ & 7 & MRI & restrospective cohort study & $\begin{array}{l}N=600 \text { patients from the Finnish Twin Cohort. } 474 \text { were included } \\
\text { in the model for disc signal and } 513 \text { in the model for disc height } \\
\text { (inclusion was dependent on availability or imaging and } \\
\text { occupational data) } \\
\text { All participants were between } 35 \text { to } 70 \text { years of age. }\end{array}$ \\
\hline
\end{tabular}

Methodological quality was assessed using the Newcastle Ottowa Assessment Scale for case control studies or cohort studies accordingly. Scores are given in starts with a maximum (higher quality) of 9 starts

133, 134, 137]. The primary method of evaluating disc degeneration is through observing disc signal intensity on imaging. Disc degeneration is often associated with a whiter less translucent appearance of the disc [126]. Of these 10 studies only two did not find significant differences between groups [3, 129] and one study found more degeneration in those with less load [127]. In one study we were not able to assess whether statistical differences existed [134]. Seven studies identified some significant difference between loading groups with more load being associated with more degeneration, although we were not able to pool the results given the differences in types of loads and outcomes measured [2, 4, 5, 126-128, 133]. For all comparisons odds ratios when calculated varied between 1.89 to 3.7. A summary of the findings is presented in Table 2. One additional study looked at an overall measure of degeneration that included a combination of factors, and found that occupational loading was associated with the overall degeneration measurements [130].

We were able to pool the results of 4 studies evaluating the association of disc degeneration with different types of occupational load for different spine levels [2-4, 133]. The results demonstrated that for all levels evaluated, including L1-S1, there was a statistically significant difference between loading groups with more degeneration associated with greater loading. Forest plost are presented in Fig. 2.

Seven studies evaluated disc height $[2,125,127,128,131$, 133, 137]. Disc height can be measured on imaging using quantitative or qualitative measures and is a surrogate measure of disc degeneration. Of the seven studies evaluating disc height only one did not find a significant difference in disc height between groups [2]. The other six studies identified some type of influence of occupation load with disc height, with greater load being associated with narrower discs. Four studies identified an overall relationship of loading with disc height, without focusing on specific levels [125, 127, 128, 137] and the other studies found different levels to be significantly different [131, 133].
Seven studies evaluated a difference in the prevalence of disc bulge or herniation [3, 126, 128, 130, 133, 136, 137]. Disc bulges or herniations were primarily evaluated through visual observation of images. Of the seven studies, five identified a significant difference between loading groups [3, 128, 133, 136, 137]. Three studies evaluated the prevalence of all lumbar levels together $[128,136,137]$ while two studies found difference for different levels, $[3,133]$ which varied between the studies. When calculated, odd ratios varied between 2.0 to 3.1.

Three studies evaluated Modic changes [126, 129, 135]. Modic changes represent lesions of the vertebral endplate that is adjacent to the bone marrow. Modic changes are often assessed qualitatively [135]. In this review only one study [135] identified a relationship of modic changes with occupation load. One study evaluated the prevalence of Schmorl's nodes [132]. These are small protrusion of the disc into the vertebral body. The one study included in this review did not identify a relationship of nodes with occupational loading groups. Two studies evaluated the presence of other endplate abnormalities, $[125,137]$ with only one study identifying a difference between loading groups [137]. Finally, three studies evaluated the presence of osteophytes [125, 132, 137] with two studies identifying greater prevalence of osteophytes in those with greater load $[125,137]$.

\section{Discussion}

The results of this study suggest that there is moderate grade evidence of an association between occupational loading and disc degeneration in terms of signal intensity. There is low quality grade evidence between loading and disc height, with inconsistent results between levels. There is low quality evidence for an association of disc bulging with occupational loading, again with inconsistent results among spinal levels. There is low quality evidence of an association between occupational loading and osteophytes, Modic changes, Schmorl's nodes and other endplate abnormalities. 


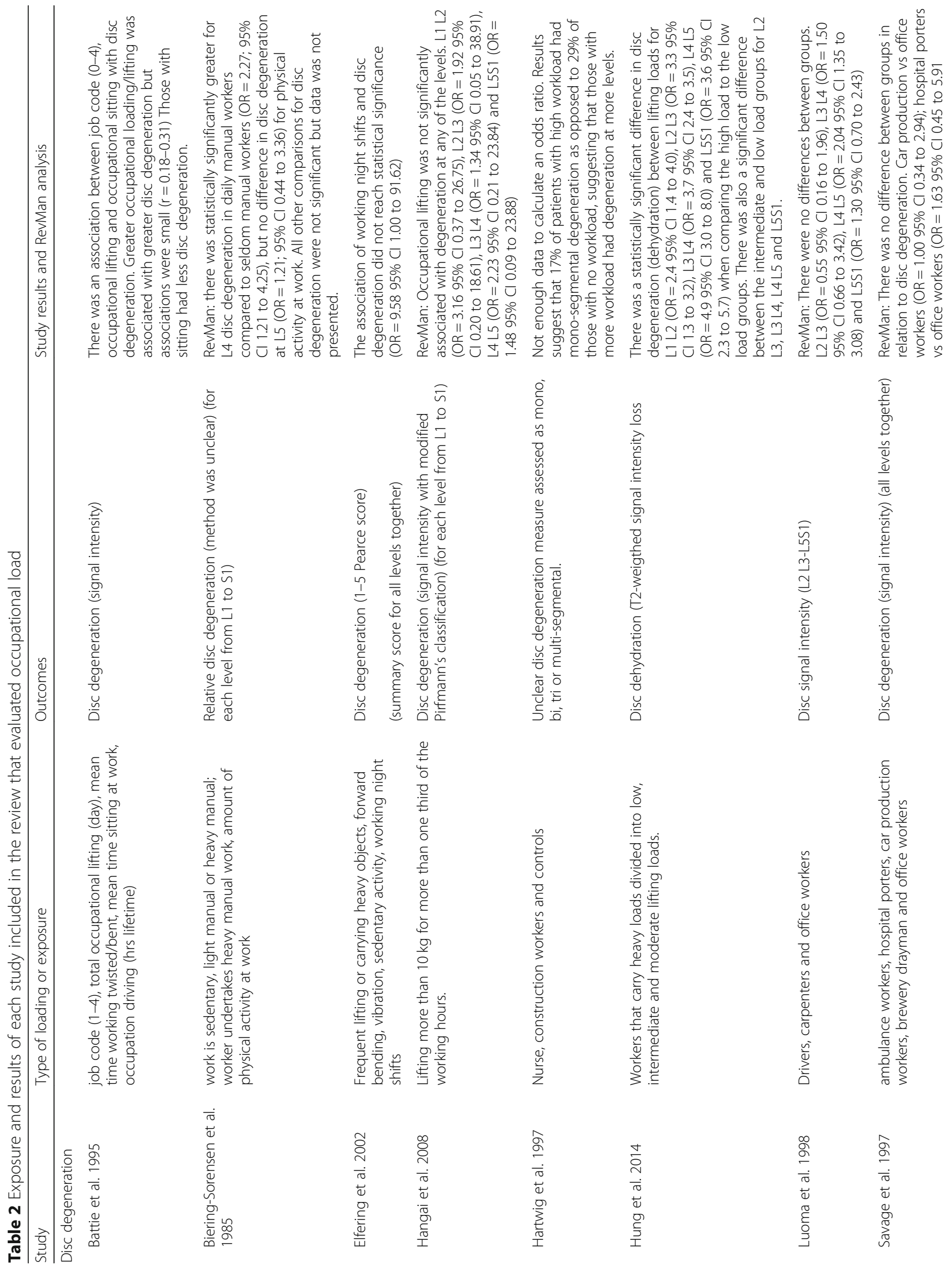




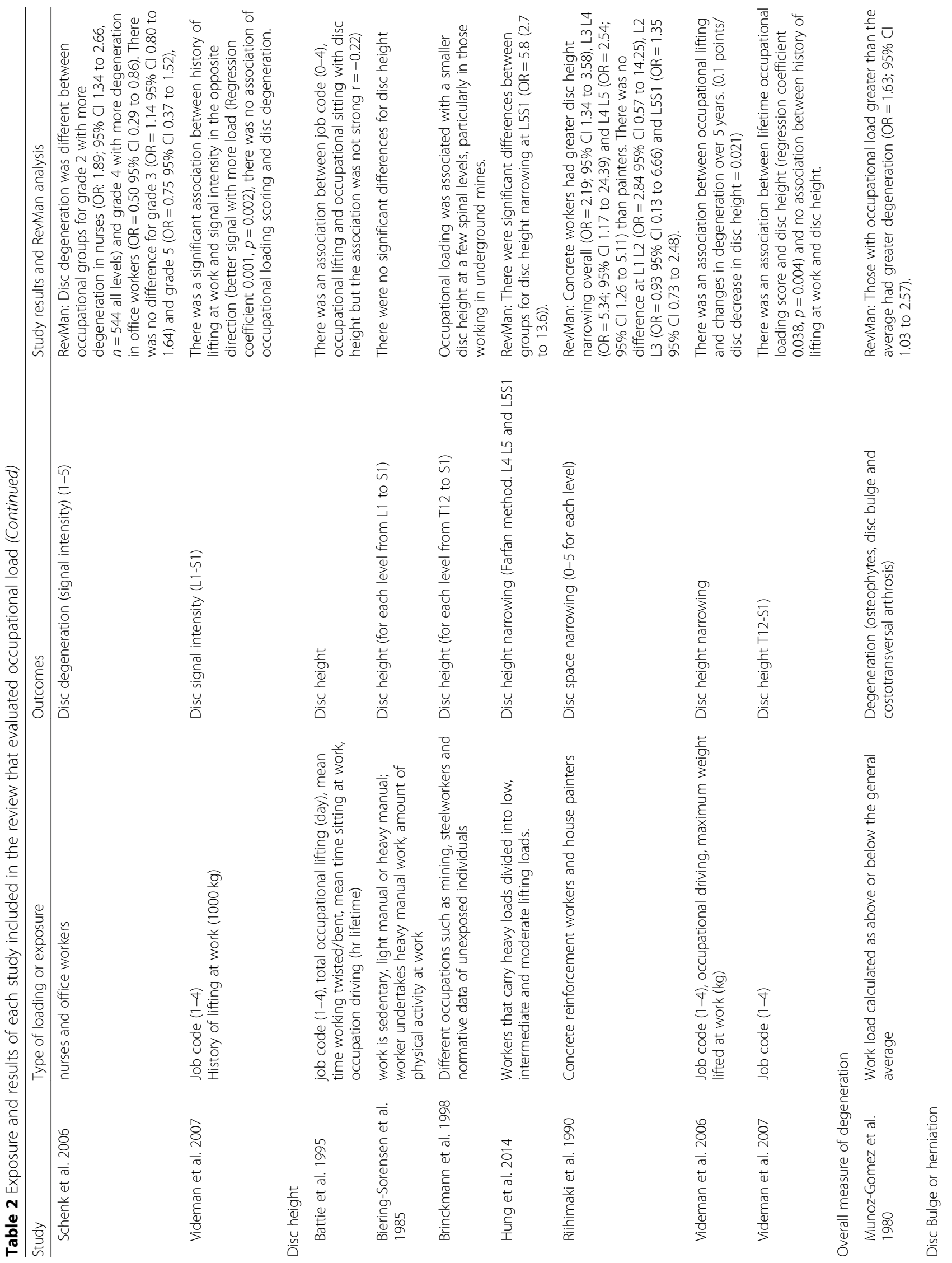




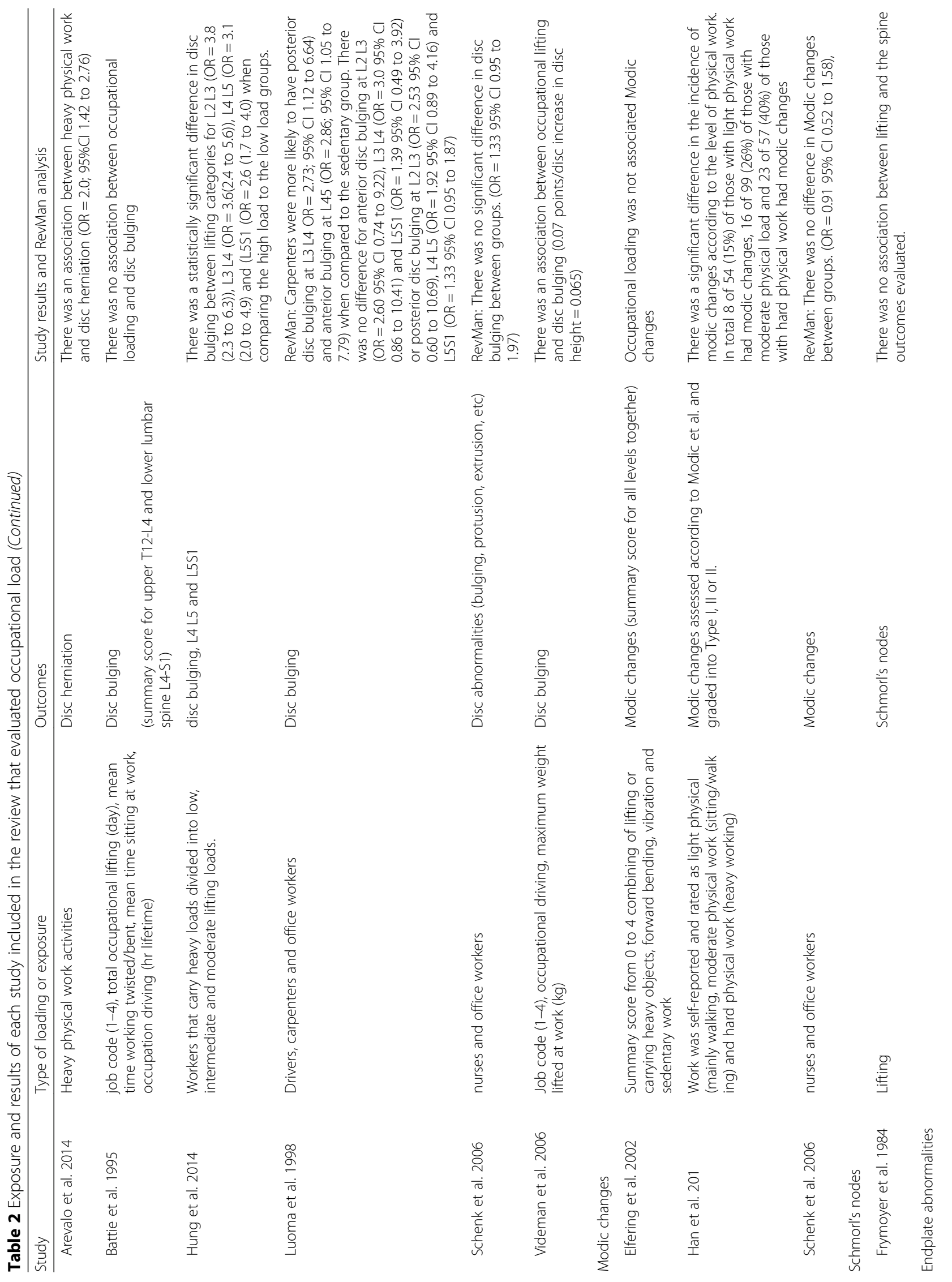


Macedo and Battié BMC Musculoskeletal Disorders

(2019) 20:489

Page 9 of 15

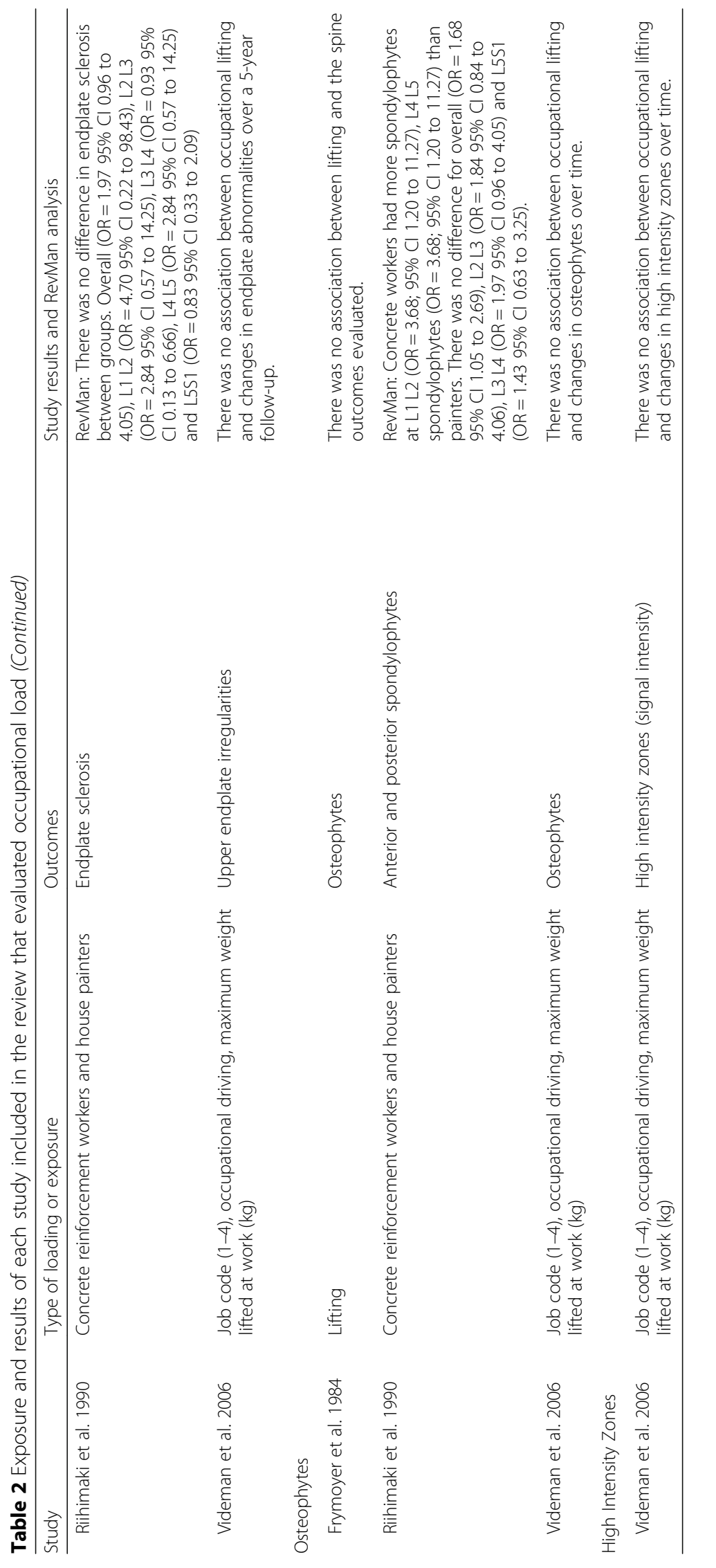




\begin{tabular}{|c|c|c|c|c|c|c|c|}
\hline Study or Subgroup & $\log \square$ & SE & Weight & IV, Fixed, $95 \% \mathrm{Cl}$ & IV, Fixed, & $95 \% \mathrm{Cl}$ & \\
\hline Hangai 2008 & 1.15 & 0.4 & $31.3 \%$ & $3.16[1.44,6.92]$ & & & \\
\hline Hung 2014 & 0.88 & 0.27 & $68.7 \%$ & $2.41[1.42,4.09]$ & & & \\
\hline Total $(95 \% \mathrm{Cl})$ & & & $100.0 \%$ & $2.62[1.69,4.07]$ & & & \\
\hline $\begin{array}{l}\text { Heterogeneity: } \mathrm{Chi}^{2}= \\
\text { Test for overall effec }\end{array}$ & & & $\begin{array}{l}=0.58) ; \\
0.0001)\end{array}$ & $F^{2}=0 \%$ & $\begin{array}{|cc|} & 1 \\
0.01 & 0.1\end{array}$ & $\begin{array}{c}10 \\
\text { Favours [control] }\end{array}$ & 100 \\
\hline
\end{tabular}

L1L2

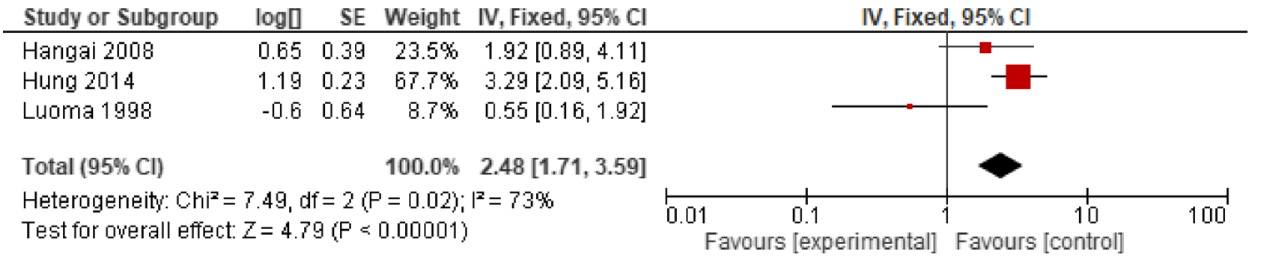

L2L3

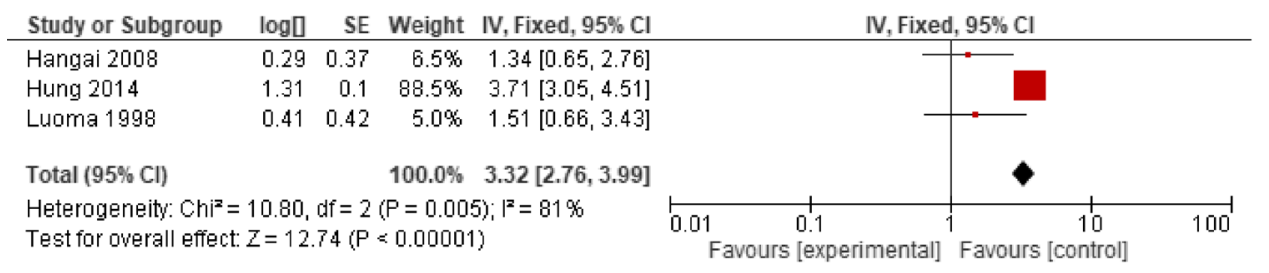

L3L4

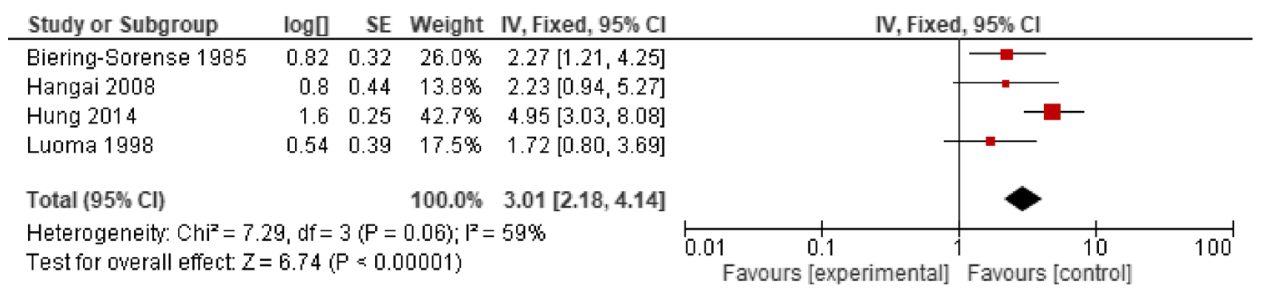

L4L5

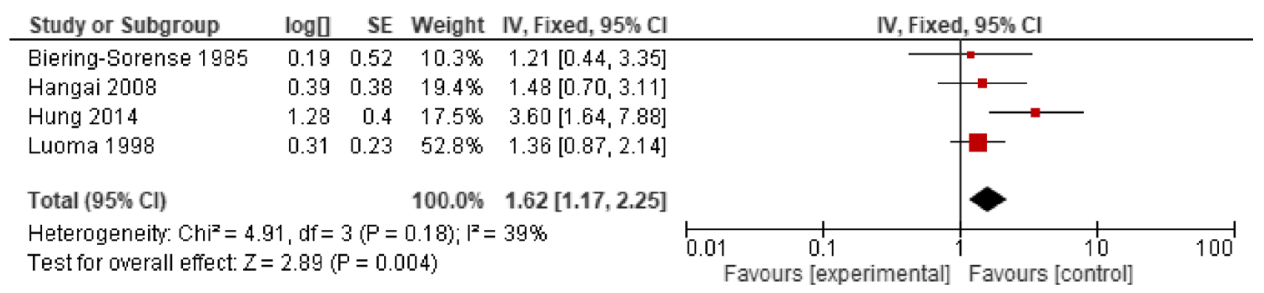

L5S1

Fig. 2 Disc degeneration (signal intensity) forest plots for each spinal level, L1-S1 
The results do suggest that occupations with greater physical loading are associated with modestly greater spine degeneration although differences in loading conditions and outcomes between studies make it is difficult to draw strong, specific conclusions. This is especially true given that positive results were inconsistently found at different spinal levels and for different outcomes. Thus, it remains difficult to draw conclusions about which type of loading may negatively affect which type of degenerative or structural findings. Additionally, different imaging methods were used (e.g. MRI, CTScans and $\mathrm{x}$-rays) and different methods to assess spine degeneration make it difficult to draw conclusions.

Limitations of the review are primarily related to the heterogeneity of the studies included. There was a wide range of types of occupational loading studied and a wide range of outcomes evaluated. Thus, although odds ratios were presented in the original manuscripts for most of the studies, it was not possible to pool the great majority of results and the findings of the review, therefore, were presented qualitatively. Finally, the poor methodological quality of some of the studies, with only a small portion assessing degeneration longitudinally, limits interpretation regarding the progression of spine degeneration.

Future research should focus on more longitudinal studies, where the development of spinal degeneration can be followed over time, with an adequate follow-up period to allow for structural changes to occur. Monozygotic twin studies should be considered, given the strength of twin study designs in minimizing possible confounding. Furthermore, individual loading exposures should be taken in consideration, especially as the activities and loading involved in any one profession can vary significantly. More specifically, the type and magnitude of loading should be depicted and evaluated in greater detail. Finally, with the advance of imaging techniques and measurement procedures, a wide variety of measures of spinal degeneration and pathology has resulted. Guidelines for measurement and better standardization of spine imaging phenotypes are needed to allow study comparisons and pooling of data to facilitate interpretation of the collective body of related research.

\section{Conclusion}

The results of this study suggest that there is moderate grade evidence of an association between occupational loading and disc degeneration in terms of signal intensity (disc degeneration). There is low or very low-quality grade evidence between loading and disc height, disc bulging, osteophytes, Modic changes, Schmorl's nodes and other endplate abnormalities. While there seems to be a modest association between heavy occupational loading and spinal degenerative findings, the limitations of the results found in this review provide a weak foundation for practical applications and related health policies.

\section{Supplementary information}

Supplementary information accompanies this paper at https://doi.org/10. 1186/s12891-019-2835-2.

Additional file 1. Search strategy section.

\section{Abbreviations \\ Cl: Confidence Interval; CTScans: Computerized Tomography scan; GRADE: Grading of Recommendations, Assessment, Development and Evaluations; LBP: Low Back Pain; MRI: Magnetic Resonance Imaging; OR: Odds ratio; r: correlation}

\section{Acknowledgments}

We would like to thank the research assistants that worked in this study and helped with data collection; Kenny Noguchi, Jennifer Nelson, Demian Carson and Christine Ha.

\section{Authors' contributions}

LM conceptualized the study, conducted searchers, data extraction, data analysis, interpretation and write up of the manuscript. MCB conceptualized the study, conducted data analysis, interpretation and write up of the manuscript. All authors have read and approved the final version of this manuscript.

\section{Funding}

No funding.

\section{Availability of data and materials}

The sources of data used in this study are available within the manuscripts and its supplementary files.

Ethics approval and consent to participate

Not applicable.

\section{Consent for publication}

Not applicable.

\section{Competing interests}

The authors declare that they have no competing interests. Dr. Macedo is an associate editor of BMC Musculoskeletal Disorders.

\section{Author details}

${ }^{1}$ School of Rehabilitation Science (Physiotherapy), Faculty of Health Sciences, McMaster University, 1400 Main St. W. Room 441, IAHS, Hamilton, ON L8S 1C7, Canada. ${ }^{2}$ Western University, London, Ontario, Canada.

Received: 22 November 2018 Accepted: 13 September 2019 Published online: 27 October 2019

\section{References}

1. Videman T, Gibbons LE, Kaprio J, Battie MC. Challenging the cumulative injury model: positive effects of greater body mass on disc degeneration. Spine J. 2010;10(1):26-31.

2. Biering-Sorensen $F$, Hansen FR, Schroll M, Runeborg O. The relation of spinal x-ray to low-back pain and physical activity among 60-year-old men and women. Spine. 1985;10(5):445-51

3. Luoma K, Riihimaki H, Raininko R, Luukkonen R, Lamminen A, Viikari-Juntura E. Lumbar disc degeneration in relation to occupation. Scand J Work Environ Health. 1998;24(5):358-66.

4. Hangai M, Kaneoka K, Kuno S, Hinotsu S, Sakane M, Mamizuka N, Sakai S, Ochiai N. Factors associated with lumbar intervertebral disc degeneration in the elderly. Spine J. 2008:8(5):732-40.

5. Savage RA, Whitehouse $\mathrm{GH}$, Roberts N. The relationship between the magnetic resonance imaging appearance of the lumbar spine and low back pain, age and occupation in males. Eur Spine J. 1997;6(2):106-14. 
6. Luoma K, Riihimaki H, Luukkonen R, Raininko R, Viikari-Juntura E, Lamminen A. Low back pain in relation to lumbar disc degeneration. Spine. 2000;25(4):487-92.

7. Chou D, Samartzis D, Bellabarba C, Patel A, Luk KDK, Kisser JMS, Skelly AC. Degenerative magnetic resonance imaging changes in patients with chronic low Back pain a systematic review. Spine. 2011;36(21):S43-53. https://doi.org/10.1097/BRS.0b013e31822ef700.

8. Hancock MJ, Maher CG, Petocz P, Lin CC, Steffens D, Luque-Suarez A, Magnussen JS. Risk factors for a recurrence of low back pain. Spine J. 2015;15:2360-8

9. The Newcastle-Ottowa Scale (NOS) for assessing the quality of nonrandomised studies in meta-analyses (2011) Ottawa Hospital Research Institute.

10. Gibbons LE, Videman T, Battie MC. Isokinetic and psychophysical lifting strength, static back muscle endurance, and magnetic resonance imaging of the paraspinal muscles as predictors of low back pain in men. Scand J Rehabil Med. 1997;29(3):187-91.

11. Higgins JPT, Green S Cochrane Handbook for Systematic Reviews of Interventions 5.1.0 [updated March 2011]. In: the Cochrane library. Chichester, UK: John Wiley \& Sons, Ltd.

12. Riihimaki H, Wickstrom G, Hanninen $K$, Mattsson T, Waris P, Zitting A. Radiographically detectable lumbar degenerative changes as risk indicators of back pain. A cross-sectional epidemiologic study of concrete reinforcement workers and house painters. Scand J Work Environ Health. 1989;15(4):280-5.

13. Edeiken J, Karasick D. Use of radiography for screening employees for risk of low-back disability. J Occup Med. 1986;28(10):995-7.

14. Campbell C, Muncer SJ. The causes of low back pain: a network analysis. Soc Sci Med. 2005;60(2):409-19.

15. Drerup B, Granitzka M, Assheuer J, Zerlett G. Assessment of disc injury in subjects exposed to long-term whole-body vibration. Eur Spine J. 1999;8(6):458-67.

16. Frymoyer JW, Rosen JC, Clements J, Pope MH. Psychologic factors in lowback-pain disability. Clin Orthop. 1985;195:178-84.

17. Karahan A, Kav S, Abbasoglu A, Dogan N. Low back pain: prevalence and associated risk factors among hospital staff. J Adv Nurs. 2009;65(3):516-24. https://doi.org/10.1111/j.1365-2648.2008.04905.x.

18. Mazloum A, Nozad H, Kumashiro M. Occupational low back pain among workers in some small-sized factories in Ardabil, Iran. Ind Health. 2006;44(1):135-9.

19. Mhaskar VA, Pai S. Does the occupational activity level affect the quality of life of patients treated with epidural steroid injections for lumbar disc herniations? Asian Spine J. 2012;6(2):131-5.

20. Omokhodion FO, Sanya AO. Risk factors for low back pain among office workers in Ibadan, Southwest Nigeria. Occup Med. 2003;53(4):287-9.

21. Palmer KT, Harris CE, Griffin MJ, Bennett J, Reading I, Sampson M, Coggon D. Case-control study of low-back pain referred for magnetic resonance imaging, with special focus on whole-body vibration. Scand J Work Environ Health. 2008;34(5):364-73.

22. Seidler A, Bolm-Audorff U, Heiskel H, Henkel N, Roth-Kuver B, Kaiser U, Bickeboller R, Willingstorfer WJ, Beck W, Elsner G. The role of cumulative physical work load in lumbar spine disease: risk factors for lumbar osteochondrosis and spondylosis associated with chronic complaints. Occup Environ Med. 2001;58(11):735-46.

23. Seidler A, Bolm-Audorff U, Siol T, Henkel N, Fuchs C, Schug H, Leheta F, Marquardt G, Schmitt E, Ulrich PT, Beck W, Missalla A, Elsner G. Occupational risk factors for symptomatic lumbar disc herniation; a case-control study. Occup Environ Med. 2003;60(11):821-30.

24. Videman T, Battie MC, Gibbons LE, Maravilha K, Manninen H, Kaprio J. Associations between back pain history and lumbar MRI findings. Spine. 2003;28(6):582-8.

25. Dasinger LK, Krause N, Deegan LJ, Brand RJ, Rudolph L. Physical workplace factors and return to work after compensated low back injury: a disability phase-specific analysis. J Occup Environ Med. 2000;42(3):323-33.

26. Zhang YG, Sun Z, Zhang Z, Liu J, Guo X. Risk factors for lumbar intervertebral disc herniation in Chinese population: a case-control study. Spine. 2009;34(25):E918-22.

27. Alund M, Larsson SE, Lewin T. Work-related persistent neck impairment: a study on former steelworks grinders. Ergonomics. 1994;37(7):1253-60.

28. Schwarze S, Notbohm G, Hartung E, Dupuis H. Effects of whole-body vibrations on the lumbar spine. Arbeitsmed Sozialmed Umweltmed. 1998; 33(10):429-42.
29. J-y J, S-I H, K-p L, Zhu J, J-I Z, Liao Y-h, Guan X, Wang X-r, Huang F. Epidemiological investigation of back pain and spondyloarthritis in Shougang resident communities. Chung Hua Nei Ko Tsa Chih. 2010;49(10): 832-5.

30. Boos N, Semmer N, Elfering A, Schade V, Gal I, Zanetti M, Kissling R, Buchegger N, Hodler J, Main CJ. Natural history of individuals with asymptomatic disc abnormalities in magnetic resonance imaging: predictors of low back pain-related medical consultation and work incapacity. Spine. 2000;25(12):1484-92.

31. Dupuis $H$, Zerlett $G$. Whole -body vibration and disorders of the spine. Int Arch Occup Environ Health. 1987;59(4):323-36.

32. Schenk P, Laubli T, Hodler J, Klipstein A. Symptomatology of recurrent low back pain in nursing and administrative professions. Eur Spine J. 2007; 16(11):1789-98.

33. Virtanen IM, Karppinen J, Taimela S, Ott J, Barral S, Kaikkonen K, Heikkila O, Mutanen P, Noponen N, Mannikko M, Tervonen O, Natri A, Ala-Kokko L. Occupational and genetic risk factors associated with intervertebral disc disease. Spine. 2007;32(10):1129-34. https://doi.org/10.1097/01.brs. $0000261473.03274 .5 \mathrm{c}$.

34. Tertti M, Paajanen H, Kujala UM, Alanen A, Salmi TT, Kormano M. Disc degeneration in young gymnast. A magnetic resonance imaging study. Am J Sports Med. 1990;18(2):206-8.

35. Tang CB, Cai RT, Yang L, Zhang GG, Li Y, Lu QF, Laurig W, Angerman K. An epidemiological study on the relationship between musculoskeletal disorders and work load. J Tongji Med Univ. 1995;15(1):59-64.

36. Leinonen V, Kankaanpaa M, Vanharanta H, Airaksinen O, Hanninen O. Back and neck extensor loading and back pain provocation in urban bus drivers with and without low back pain. Pathophysiology. 2005;12(4):249-55.

37. Seidler A, Euler U, Bolm-Audorff U, Ellegast R, Grifka J, Haerting J, Jager M, Michaelis M, Kuss O. Physical workload and accelerated occurrence of lumbar spine diseases: risk and rate advancement periods in a German multicenter case-control study. Scand J Work Environ Health. 2011:37(1):30-6.

38. Bos E, Krol B, van der Star L, Groothoff J. Risk factors and musculoskeletal complaints in non-specialized nurses, IC nurses, operation room nurses, and X-ray technologists. Int Arch Occup Environ Health. 2007;80(3):198-206.

39. Granhed H, Morelli B. Low back pain among retired wrestlers and heavyweight lifters. Am J Sports Med. 1988;16(5):530-3.

40. Tiemessen IJH, Hulshof CTJ, Frings-Dresen MHW. Low back pain in drivers exposed to whole body vibration: analysis of a dose-response pattern. Occup Environ Med. 2008;65(10):667-75.

41. Macdonald EB, Porter R, Hibbert C, Hart J. The relationship between spinal canal diameter and back pain in coal miners. Ultrasonic measurement as a screening test? J Occup Med. 1984;26(1):23-8.

42. Aharony S, Milgrom C, Wolf T, Barzilay $Y$, Applbaum YH, Schindel $Y$, Finestone A, Liram N. Magnetic resonance imaging showed no signs of overuse or permanent injury to the lumbar sacral spine during a special forces training course. Spine J. 2008;8(4):578-83.

43. Landau DA, Chapnick L, Yoffe N, Azaria B, Goldstein L, Atar E. Cervical and lumbar MRI findings in aviators as a function of aircraft type. Aviat Space Environ Med. 2006;77(11):1158-61.

44. Baumann F, Beck A. Work-related spinal damage in jet pilots due to extreme acceleration. Z Orthop Ihre Grenzgeb. 1975;113(4):645-8.

45. Kristen $H$, Lukeschitsch $G$, Ramach $W$. Investigation of the lumbar vertebral column in light-transport workers. Arbeitsmed Sozialmed Praventivmed. 1981;16(9):226-9.

46. Sharma A, Lancaster S, Bagade S, Hildebolt C. Early pattern of degenerative changes in individual components of intervertebral discs in stressed and nonstressed segments of lumbar spine: an in vivo magnetic resonance imaging study. Spine. 2014;39(13):1084-90.

47. Videman T, Battie MC, Gibbons LE, Manninen H, Gill K, Fisher LD, Koskenvuo M. Lifetime exercise and disk degeneration: an MRI study of monozygotic twins. Med Sci Sports Exerc. 1997;29(10):1350-6.

48. Kelsey $\mathrm{JL}$. An epidemiological study of the relationship between occupations and acute herniated lumbar intervertebral discs. Int J Epidemiol. 1975;4(3):197-205

49. Auerbach JD, Weidner ZD, Milby AH, Diab M, Lonner BS. Musculoskeletal disorders among spine surgeons: results of a survey of the scoliosis research society membership. Spine. 2011;36(26):E1715-21.

50. Bishop MD, Horn ME, Lott DJ, Arpan I, George SZ. Magnitude of spinal muscle damage is not statistically associated with exercise-induced low back pain intensity. Spine J. 2011;11(12):1135-42. 
51. Boos N, Rieder R, Schade V, Spratt KF, Semmer N, Aebi M. 1995 Volvo award in clinical sciences. The diagnostic accuracy of magnetic resonance imaging, work perception, and psychosocial factors in identifying symptomatic disc herniations. Spine. 1995;20(24):2613-25.

52. Liuke M, Solovieva S, Lamminen A, Luoma K, Leino-Arjas P, Luukkonen R, Riihimaki $H$. Disc degeneration of the lumbar spine in relation to overweight. Int J Obes. 2005;29(8):903-8.

53. Mattila VM, Sillanpää P, Visuri T, Pihlajamäki H. Incidence and trends of low back pain hospitalisation during military service--an analysis of 387,070 Finnish young males. BMC Musculoskelet Disord. 2009;10:10. https://doi.org/ 10.1186/1471-2474-10-10.

54. Carragee EJ, Alamin TF, Miller JL, Carragee JM. Discographic, MRI and psychosocial determinants of low back pain disability and remission: a prospective study in subjects with benign persistent back pain. Spine J. 2005;5(1):24-35.

55. Simmons ED Jr, Guntupalli M, Kowalski JM, Braun F, Seidel T. Familial predisposition for degenerative disc disease. A case-control study. Spine. 1996;21(13):1527-9.

56. Sambrook PN, MacGregor AJ, Spector TD. Genetic influences on cervical and lumbar disc degeneration: a magnetic resonance imaging study in twins. Arthritis Rheum. 1999;42(2):366-72.

57. Karppinen J, Daavittila I, Solovieva S, Kuisma M, Taimela S, Natri A, Haapea M, Korpelainen R, Niinimaki J, Tervonen O, Ala-Kokko L, Mannikko M. Genetic factors are associated with modic changes in endplates of lumbar vertebral bodies. Spine. 2008;33(11):1236-41.

58. Livshits G, Popham M, Malkin I, Sambrook PN, MacGregor AJ, Spector T, Williams FMK. Lumbar disc degeneration and genetic factors are the main risk factors for low back pain in women: the UK twin spine study. Ann Rheum Dis. 2011;70(10):1740-5

59. Aggrawal ND, Kaur R, Kumar S, Mathur DN. A study of changes in the spine in weight lifters and other athletes. Br J Sports Med. 1979;13(2):58-61.

60. Pye SR, Reid DM, Adams JE, Silman AJ, O'Neill TW. Influence of weight, body mass index and lifestyle factors on radiographic features of lumbar disc degeneration. Ann Rheum Dis. 2007;66:426-7.

61. Cheung KMC, Karppinen J, Chan D, Ho DWH, Song Y-Q, Sham P, Cheah KSE, Leong JCY, Luk KDK. Prevalence and pattern of lumbar magnetic resonance imaging changes in a population study of one thousand forty-three individuals. Spine. 2009;34(9):934-40. https://doi.org/10.1097/BRS. Ob013e3181a01b3f.

62. Suri P, Hunter DJ, Boyko EJ, Rainville J, Guermazi A, Katz JN. Physical activity and associations with computed tomography-detected lumbar zygapophyseal joint osteoarthritis. Spine J. 2015;15(1):42-9.

63. Franco JL (2008) Modic changes: "Age, si quid agis"... Eur Spine J 2006 Sep; 15(9):1312-1319. Eur Spine J 17 (12):1766-1768.

64. Rainville J, Kim RS, Katz JN. A review of 1985 Volvo award winner in clinical science: objective assessment of spine function following industrial injury: a prospective study with comparison group and 1-year follow-up. Spine. 2007;32(18):2031-4.

65. Williams FM, Sambrook PN. Neck and back pain and intervertebral disc degeneration: role of occupational factors. Baillieres Best Pract Res Clin Rheumatol. 2011;25(1):69-79. https://doi.org/10.1016/j.berh.2011.01.007.

66. Chaffin DB. Manual materials handling: the cause of over-exertion injury and illness in industry. J Environ Pathol Toxicol. 1979:2(5):31-66.

67. Harley WJ. Lost time back injuries: their rrelationship to heavy work and preplacement back x-rays. J Occup Med. 1972;14(8):611-4.

68. Borenstein DG, Burton JR. Lumbar spine disease in the elderly. J Am Geriatr Soc. 1993;41(2):167-75.

69. Williams FMK, Popham M, Livshits G, Sambrook PN, Spector TD, MacGregor AJ. A response to Videman et al., "challenging the cumulative injury model: positive effects of greater body mass on disc degeneration". Spine J. 2010; 10(6):571-2

70. Videman T, Nurminen M, Troup JD. 1990 Volvo award in clinical sciences. Lumbar spinal pathology in cadaveric material in relation to history of back pain, occupation, and physical loading. Spine. 1990;15(8):728-40.

71. Arun R, Freeman BJ, Scammell BE, MCNally DS, Cox E, Gowland P. 2009 ISSLS prize winner: what influence does sustained mechanical load have on diffusion in the human intervertebral disc?: an in vivo study using serial postcontrast magnetic resonance imaging. Spine. 2009;34(21):2324-37.

72. Belfi LM, Ortiz AO, Katz DS. Computed tomography evaluation of spondylolysis and spondylolisthesis in asymptomatic patients. Spine. 2006; 31(24):E907-10.
73. Boos N, Rieder R, Schade V, Spratt KF, Semmer N, Aebi M. The diagnostic accuracy of magnetic resonance imaging, work perception, and psychosocial factors in identifying symptomatic disc herniations. Spine. 1995;20(24):2613-25.

74. Farfan HF, Cossette JW, Robertson GH, Wells RV, Kraus H. The effects of torsion on the lumbar intervertebral joints: the role of torsion in the production of disc degeneration. J Bone Joint Surg Am. 1970;52(3):468-97.

75. Gunning JL, Callaghan JP, McGill SM. Spinal posture and prior loading history modulate compressive strength and type of failure in the spine: a biomechanical study using a porcine cervical spine model. Clin Biomech. 2001;16(6):471-80.

76. Olsewski JM, Schendel MJ, Wallace LJ, Ogilvie JW, Gundry CR. Magnetic resonance imaging and biological changes in injured intervertebral discs under normal and increased mechanical demands. Spine. 1996; 21(17):1945-51.

77. Bible JE, Choemprayong S, O'Neill K, Devin CJ, Spengler DM. Whole-body vibration. Is there a causal relationship to specific imaging findings of the spine? Spine. 2012;37(21):E1348-55.

78. Gooyers CE, McMillan RD, Howarth SJ, Callaghan JP. The impact of posture and prolonged cyclic compressive loading on vertebral joint mechanics. Spine. 2012;37(17):E1023-9.

79. Stemper BD, Baisden J, Yogamandan N, Pintar FA, Tarima S, Xiang Q, Paskoff GR, Shender BS. Lumbar spine injury tolerance during high-rate axial loading. Spine J. 2013;13:13S-4S.

80. Brinckmann P, Frobin W, Biggemann M, Hilweg D, Seidel S, Burton K, Tillotson M, Sandover J, Atha J, Quinnell R. Quantification of overload injuries to thoracolumbar vertebrae and discs in persons exposed to heavy physical exertions or vibration at the work-place. Clin Biomech. 1994;9(SUPPL. 1):S1-S83.

81. Arora M, Paoloni JA, Kandwal P, Diwan AD. Are fast-bowlers prone to back injuries? Prevalence of lumbar spine injuries in fast-bowlers: review of MRIbased studies. Asian J Sports Med. 2014;5(4):e24291.

82. Seidler A, Bergmann A, Jager M, Ellegast R, Ditchen D, Elsner G, Grifka J, Haerting J, Hofmann F, Linhardt O, Luttmann A, Michaelis M, Petereit-Haack G, Schumann B, Bolm-Audorff U. Cumulative occupational lumbar load and lumbar disc disease--results of a German multi-center case-control study (EPILIFT). BMC Musculoskelet Disord. 2009;10:48.

83. Sun ZM, Ling M, Chang YH, Liu ZZ, Xu HH, Gong LQ, Liu J, Zhang YG. Casecontrol study of the risk factors of lumbar intervertebral disc herniation in 5 northern provinces of China. Nan Fang Yi Ke Da Xue Xue Bao. 2010;30(11): 2488-91.

84. Nienhaus A, Elsner G, Beck W. Degenerative discopathies of occupational origin in the region of the lumbar spine. Arbeitsmed Sozialmed Praventivmed. 1992;27(10):415-22.

85. Liu S, Zhang H, Liu X, Shen Y, Dai W, Ju Z, Ma J, Xu W. Study on vertebral degenerations of coal miners with low back pain by means of computerized tomography. Zhonghua Lao Dong Wei Sheng Zhi Ye Bing Za Zhi. 2002:20(1):10-2.

86. Bergmann A, Meisel HJ, Bolm-Audorff U, Ditchen D, Ellegast R, Elsner G, Grifka J, Haerting J, Hoffmann F, Jager M, Linhardt O, Luttmann A, Michaelis M, Petereit-Haack G, Schumann B, Seidler A (2010) Physical workload - a relevant factor for developing lumbar disc diseases (German spine study epilift). Spine conference (journal article):38th.

87. Mariconda M, Galasso O, Imbimbo L, Lotti G, Milano C. Relationship between alterations of the lumbar spine, visualized with magnetic resonance imaging, and occupational variables. Eur Spine J. 2007; 16(2):255-66

88. Vanharanta H, Heliovaara M, Korpi J, Troup JD. Occupation, work load and the size and shape of lumbar vertebral canals. Scand J Work Environ Health. 1987;13(2):146-9.

89. Shambrook J, McNee P, Harris E, Kim M, Sampson M, Palmer K, Coggan D. Clinical presentation of low back pain and association with risk factors according to findings on magnetic resonance imaging. Pain. 2011;152:1659-65

90. Saberi H, Rahimi L, Jahani L. A comparative MRI study of upper and lower lumbar motion segments in patients with low back pain. J Spinal Disord Tech. 2009;22(7):507-10.

91. Palmer KT, Griffin M, Ntani G, Shambrook J, McNee P, Sampson M, Harris EC, Coggon D. Professional driving and prolapsed lumbar intervertebral disc diagnosed by magnetic resonance imaging: a casecontrol study. Scand J Work Environ Health. 2012;38(6):577-81. https://doi.org/10.5271/sjweh.3273. 
92. Rossi A, Marino G, Barbieri L, Borrelli A, Onofri C, Rolli M, Baldi R. Backache from exertion in health personnel of the Istituti Ortopedici Rizzoli in Bologna. A case-control study of the injury phenomenon in the 10-year period of 1987-1996. Epidemiol Prev. 1999;23(2):98-104.

93. Bridger RS, Groom MR, Jones H, Pethybridge RJ, Pullinger N. Task and postural factors are related to back pain in helicopter pilots. Aviat Space Environ Med. 2002;73(8):805-11.

94. Nohejl J, Dostal C, Faberova R, Malecek J, Roth Z, Trnavsky K. Preliminary results of an epidemiological study of back pain in a Prague population. Czech Med. 1987;10(2):117-24.

95. Birlik G. Occupational exposure to whole body vibration-train drivers. Ind Health. 2009;47(1):5-10.

96. Elsner G, Nienhaus A, Beck W. Occupationally-induced degenerative discopathies in the area of the lumbar spine. Soz Praventivmed. 1997:42(3):144-54.

97. Hamalainen O, Vanharanta H, Kuusela T. Degeneration of cervical intervertebral disks in fighter pilots frequently exposed to high $+\mathrm{Gz}$ forces. Aviat Space Environ Med. 1993;64(8):692-6.

98. Joosab M, Torode M, Rao PV. Preliminary findings on the effect of loadcarrying to the structural integrity of the cervical spine. Surg Radiol Anat. 1994;16(4):393-8.

99. Kartal A, Yildiran I, Senkoylu A, Korkusuz F. Soccer causes degenerative changes in the cervical spine. Eur Spine J. 2004;13(1):76-82.

100. Danckwerth F, Castro WHM, Assheuer J. Morphological changes at the cervical spine among professional string instrument players? Zentralbl Arbeitsmed Arbeitsschutz Ergonomie. 1996;46(10):362-9.

101. Wang Y, Owoc JS, Boyd SK, Videman T, Battie MC. Occupational loading may not affect the association between vertebral trabecular bone and intervertebral disc narrowing. Bone. 2013;57(2):375-6. https:/doi.org/10.1016/j.bone.2013.09.005.

102. Bakhtiar CS, Suneetha S, Vijay R. Conservative approaches benefit occupation-related backaches in milk-vendors and goldsmiths. Indian J Occup Environ Med. 2002;6(4):186-8.

103. Kuisma M, Karppinen J, Niinimaki J, Ojala R, Haapea M, Heliovaara M, Korpelainen R, Taimela S, Natri A, Tervonen O. Modic changes in endplates of lumbar vertebral bodies: prevalence and association with low back and sciatic pain among middle-aged male workers. Spine. 2007;32(10):1116-22.

104. Battie MC, Videman T, Levalahti E, Gill K, Kaprio J. Heritability of low back pain and the role of disc degeneration. Pain. 2007;131:272-80.

105. Videman T, Battie MC, Parent E, Gibbons LE, Vainio P, Kaprio J. Progression and determinants of quantitative magnetic resonance imaging measures of lumbar disc degeneration: a five-year follow-up of adult male monozygotic twins. Spine. 2008;33(13):1484-90.

106. Hendriksen IJ, Holewijn M. Degenerative changes of the spine of fighter pilots of the Royal Netherlands air Force (RNLAF). Aviat Space Environ Med. 1999;70(11):1057-63.

107. Kuisma M, Karppinen J, Haapea M, Niinimaki J, Ojala R, Heliovaara M, Korpelainen R, Kaikkonen K, Taimela S, Natri A, Tervonen O. Are the determinants of vertebral endplate changes and severe disc degeneration in the lumbar spine the same? A magnetic resonance imaging study in middle-aged male workers. BMC Musculoskelet Disord. 2008;9:51.

108. Kumar A, Varghese M, Mohan D, Mahajan P, Gulati P, Kale S. Effect of whole-body vibration on the low back. A study of tractor-driving farmers in North India. Spine. 1999;24(23):2506-15.

109. Videman T, Simonen R, Usenius J, Osterman K, Battie M. The long-term effects of rally driving on spinal pathology. Clin Biomech. 2000;15(2):83-6.

110. Sovelius R, Salonen O, Lamminen A, Huhtala H, Hamalainen O. Spinal MRI in fighter pilots and controls: a 13-year longitudinal study. Aviat Space Environ Med. 2008;79(7):685-8.

111. Battie MC, Videman T, Gibbons LE, Manninen H, Gill K, Pope M, Kaprio J. Occupational driving and lumbar disc degeneration: a case-control study. Lancet. 2002;360(9343):1369-74.

112. Aydog ST, Turbedar E, Demirel AH, Tetik O, Akin A, Doral MN. Cervical and lumbar spinal changes diagnosed in four-view radiographs of 732 military pilots. Aviat Space Environ Med. 2004;75(2):154-7.

113. Byeon JH, Kim JW, Jeong HJ, Sim YS, Kim DK, Choi JK, Im HJ, Kim GC. Degenerative changes of spine in helicopter pilots. Ann Rehabil Med. 2013; 37(5):706-12.

114. Fischer V, Witt AN, Troeger C. Vibration-induced injuries to the vertebral column of helicopter pilots. Arbeitsmed Sozialmed Praventivmed. 1980;15(7):161-3.

115. Christ W, Dupuis H (1968) Studies on the possibility of physical damage to the spinal area in tractor operators. II. Report on the $2 \mathrm{~d}$ mass examination of 137 young farmers. Med welt 37 (journal article):1967-1972.
116. Kaneoka K, Shimizu K, Hangai M, Okuwaki T, Mamizuka N, Sakane M, Ochiai N. Lumbar intervertebral disk degeneration in elite competitive swimmers a case control study. Am J Sports Med. 2007;35(8):1341-5. https://doi.org/10. $1177 / 0363546507300259$.

117. Baranto A, Hellstrom M, Cederlund CG, Nyman R, Sward L. Back pain and MRI changes in the thoraco-lumbar spine of top athletes in four different sports: a 15-year follow-up study. Knee Surg Sports Traumatol Arthrosc. 2009;17(9):1125-34.

118. Ichikawa N, Ohara Y, Morishita T, Taniguichi Y, Koshikawa A, Matsukura N. An aetiological study on spondylolysis from a biomechanical aspect. $\mathrm{Br} J$ Sports Med. 1982;16(3):135-41.

119. Videman T, Sarna S, Battie MC, Koskinen S, Gill K, Paananen H, Gibbons L. The long-term effects of physical loading and exercise lifestyles on backrelated symptoms, disability, and spinal pathology among men. Spine. 1995; 20(6):699-709.

120. Rachbauer F, Sterzinger W, Eibl G. Radiographic abnormalities in the thoracolumbar spine of young elite skiers. Am J Sports Med. 2001;29(4):446-9.

121. Ozturk B, Gunduz OH, Ozoran K, Bostanoglu S. Effect of continuous lumbar traction on the size of herniated disc material in lumbar disc herniation. Rheumatol Int. 2006;26(7):622-6.

122. Nagashima $M$, Abe $H$, Amaya $K$, Matsumoto $H$, Yanaihara $H$, Nishiwaki $Y$, Toyama Y, Matsumoto M. Risk factors for lumbar disc degeneration in high school American football players a prospective 2-year follow-up study. Am J Sports Med. 2013;41(9):2059-64. https://doi.org/10.1177/0363546513495173.

123. Kraft CN, Pennekamp PH, Becker U, Young M, Diedrich O, Luering C, von Falkenhausen M. Magnetic resonance imaging findings of the lumbar spine in elite horseback riders correlations with Back pain, body mass index, trunk/leg-length coefficient, and riding discipline. Am J Sports Med. 2009; 37(11):2205-13. https://doi.org/10.1177/0363546509336927.

124. Vadala G, Russo F, Battisti S, Stellato L, Martina F, Del Vescovo R, Giacalone A, Borthakur A, Zobel BB, Denaro V. Early intervertebral disc degeneration changes in asymptomatic weightlifters assessed by t1p-magnetic resonance imaging. Spine. 2014;39(22):1881-6.

125. Riihimaki $H$, Mattsson $T$, Zitting A, Wickstrom G, Hanninen $K$, Waris $P$ Radiographically detectable degenerative changes of the lumbar spine among concrete reinforcement workers and house painters. Spine. 1990; 15(2):114-9.

126. Schenk P, Laubli T, Hodler J, Klipstein A. Magnetic resonance imaging of the lumbar spine: findings in female subjects from administrative and nursing professions. Spine. 2006;31(23):2701-6.

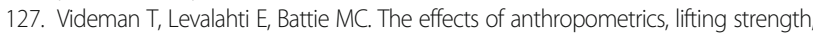
and physical activities in disc degeneration. Spine. 2007;32(13):1406-13.

128. Battie MC, Videman T, Gibbons LE, Fisher LD, Manninen H, Gill K (1995) 1995 Volvo award in clinical sciences. Determinants of lumbar disc degeneration. A study relating lifetime exposures and magnetic resonance imaging findings in identical twins Spine 20 (24):2601-2612.

129. Elfering A, Semmer N, Birkhofer D, Zanetti M, Hodler J, Boos N. Risk factors for lumbar disc degeneration: a 5-year prospective MRI study in asymptomatic individuals. Spine. 2002;27(2):125-34.

130. Munoz-Gomez J, Bernades-Bernat E, Valenzuela-Castano A, Duro-Pujol JC. Clinico-radiological correlation of the dorsal spine in a population of workers. Rev Rhum Mal Osteoartic. 1980;47(3):175-80.

131. Brinckmann P, Frobin W, Biggeman M, Tillotson M, Burton K. Quantification of overload injuries to thoracolumbar vertebrae and discs in persons exposed to heavy physical exertions or vibration at the workplace. Part II. Occurrence and magnitude of overload injury in exposed cohorts. Clin Biomech. 1998;13(SUPPL. 2):S36.

132. Frymoyer JW, Newberg A, Pope MH, Wilder DG, Clements J, MacPherson B. Spine radiographs in patients with low-back pain. An epidemiological study in men. J Bone Joint Surg Am. 1984;66(7):1048-55.

133. Hung YJ, Shih TT, Chen BB, Hwang YH, Ma LP, Huang WC, Liou SH, Ho IK, Guo YL. The dose-response relationship between cumulative lifting load and lumbar disk degeneration based on magnetic resonance imaging findings. Phys Ther. 2014;94(11):1582-93.

134. Hartwig E, Hoellen I, Liener U, Kramer M, Wickstroem M, Kinzl L. Occupational disease 2108. Degeneration pattern in magnetic resonance tomography of the lumbar spine in patient with differential weight-bearing activity. Unfallchirurg. 1997;100(11):888-94.

135. Han C, Kuang MJ, Ma JX, Ma XL. Prevalence of Modic changes in the lumbar vertebrae and their associations with workload, smoking and weight in northern China. Sci Rep. 2017;7:46341. https://doi.org/10.1038/srep46341. 
136. Arevalo G, Varela C, Gijon L, Rosas ML, Arevalo F. Modifiable risk factors and lumbar disc herniation: results of a case control study in 652 patients. Ann Phys Rehabil Med. 2014;57:e197.

137. Videman T, Battie MC, Ripatti S, Gill K, Manninen H, Kaprio J. Determinants of the progression in lumbar degeneration: a 5-year follow-up study of adult male monozygotic twins. Spine. 2006;31(6):671-8.

\section{Publisher's Note}

Springer Nature remains neutral with regard to jurisdictional claims in published maps and institutional affiliations.

Ready to submit your research? Choose BMC and benefit from:

- fast, convenient online submission

- thorough peer review by experienced researchers in your field

- rapid publication on acceptance

- support for research data, including large and complex data types

- gold Open Access which fosters wider collaboration and increased citations

- maximum visibility for your research: over $100 \mathrm{M}$ website views per year

At BMC, research is always in progress.

Learn more biomedcentral.com/submissions 